\title{
ŚRODKI NADZORU ELIMINUJĄCE WADLIWE ROZSTRZYGNIĘCIA ORGANÓW GMINY - PRÓBA OCENY PRZYJĘTYCH ROZWIAZZAŃ W ŚWIETLE EUROPEJSKIEJ KARTY SAMORZĄDU LOKALNEGO
}

\section{WPROWADZENIE}

Jedną z ważniejszych reform wdrażanych w Polsce po 1989 r., stanowiących przejaw decentralizacji państwa, było reaktywowanie samorządu terytorialnego. Ustawą z 1990 r. o samorządzie terytorialnym ${ }^{1}$ przywrócono samorząd terytorialny na poziomie gminy, dając wyraz zrozumieniu idei współczesnego państwa prawa. Przyjęte rozwiązania nawiązywały do wyrażonego w Europejskiej karcie samorządu lokalnego ${ }^{2}$ przeświadczenia, że zjednoczoną Europę budować można jedynie z odwołaniem się do zorganizowanych na wspólnych założeniach społeczności lokalnych, powierzając im do samodzielnej realizacji znaczącą część zadań publicznych.

Trzydzieści lat funkcjonowania samorządności terytorialnej w Polsce stanowi okazję do podjęcia próby oceny przyjętych wówczas rozwiązań oraz kierunków ich zmian. Charakter opracowania zdeterminował ograniczenie się w opracowaniu do analizy środków nadzoru nakierowanych na niestanowiące rozstrzygnięć w rozumieniu k.p.a. ${ }^{3}$ uchwały i zarządzenia wydawane odpowiednio przez organy stanowiące oraz wykonawcze podstawowych jednostek samorządowych, tj. gmin.

Nadany ustawą kształt systemu samorządności terytorialnej w Polsce nie mógł odwoływać się do wówczas obowiązujących rozwiązań konstytucyjnych. Konstytucja z 1952 r. ${ }^{4}$, przyjmując zasadę jednolitej władzy państwowej,

${ }^{1}$ Ustawa z 8 marca 1990 r. o samorządzie terytorialnym, Dz. U. 1990, Nr 16, poz. 95 (dalej jako: u.s.t.).

W wyniku nowelizacji z 29 grudnia 1998 r. tytuł ustawy otrzymał brzmienie - ustawa z 8 marca 1990 r. o samorządzie gminnym, t.jedn.: Dz. U. 2020, poz. 713 (dalej jako: u.s.g.).

${ }^{2}$ Europejska karta samorządu lokalnego przyjęta przez Stałą Konferencję Gmin i Regionów Europy przy Radzie Europy w Strasburgu 15 października 1985 r. (dalej jako: EKSL lub Karta), ratyfikowana przez Polskę w 1993 r. (Dz. U. 1994, Nr 124, poz. 608).

${ }^{3}$ Ustawa z 14 czerwca 1960 r. - Kodeks postępowania administracyjnego, t.jedn.: Dz. U. 2020 poz. 256 (dalej jako: k.p.a.).

${ }^{4}$ Konstytucja Polskiej Rzeczypospolitej Ludowej uchwalona przez Sejm Ustawodawczy 22 lipca 1952 r., t.jedn.: Dz. U. 1976, Nr 7, poz. 36. 
wykluczała istnienie samodzielnego, wyposażonego w odrębną od państwa podmiotowość, samorządu terytorialnego. Nowelizacja Konstytucji z 1952 r. ustawa z 8 marca 1990 r. ${ }^{5}$ określiła podstawy ustroju i działania samorzą$\mathrm{du}$ terytorialnego, milcząc jednak na temat nadzoru. Ustawa konstytucyjna z 1992 r. ${ }^{6}$ uregulowano kluczowe kwestie dotyczące organizacji i funkcjonowania samorządu terytorialnego, sprawy nadzoru pozostawiając do uregulowania w drodze ustaw (art. 74 ustawy konstytucyjnej z 1992 r.).

Konstytucja z $1997 \mathrm{r}^{7}$ wprowadzono rozwiązania pozostajace pod wpływem ratyfikowanej przez Polskę w roku 1993 EKSL, spełniając najwyższe standardy nią określone. W Konstytucji, w rozdz. 7: „Samorząd terytorialny", powołano samorząd terytorialny na poziomie gminy, ustawodawcy pozostawiając utworzenie samorządu na innych poziomach (art. 164 ust. 1-2), przewidziano wykonywanie nadzoru wyłącznie z punktu widzenia legalności (art. 171 ust. 1) oraz określono katalog organów nadzoru: Prezes Rady Ministrów, wojewodowie oraz regionalne izby obrachunkowe (art. 171 ust. 2$)^{8}$. Nie przewidziano możliwości wprowadzenia innych kryteriów nadzoru oraz możliwości rozszerzenia katalogu organów nadzoru w drodze ustawowej ${ }^{9}$. Jednak nie wszystkie szczegółowe regulacje ustawowe oraz próby ich zmian ocenić można jednoznacznie pozytywnie.

\section{CHARAKTERYSTYKA PRZYJĘTYCH W EKSL ZASAD SPRAWOWANIA NADZORU NAD SAMORZĄDEM TERYTORIALNYM}

Silny samorząd długo przed przyjęciem Karty postrzegany był jako fundament demokratycznego, zdecentralizowanego państwa prawa. W Karcie dano wyraz przeświadczeniu, że bez zaangażowania w realizację lokalnych zadań publicznych społeczności, których one bezpośrednio dotycza, nie da się urzeczywistnić idei demokratycznego państwa prawa ${ }^{10}$.

Ustalając przyjęty Kartą (art. 8) katalog zasad sprawowania nadzoru, nie można pomijać wartości wyrażonych w innych przepisach, które zdeterminowały jego treść ${ }^{11}$. Dotyczy to zwłaszcza art. 3 EKSL, w którym wskazano, że

${ }^{5}$ Ustawa z 8 marca 1990 r. o zmianie Konstytucji Rzeczypospolitej Polskiej, Dz. U. 1990, Nr 16, poz. 94.

${ }^{6}$ Ustawa Konstytucyjna z 17 października 1992 r. o wzajemnych stosunkach między władzą ustawodawczą i wykonawczą Rzeczypospolitej Polskiej oraz o samorządzie terytorialnym.

${ }^{7}$ Konstytucja Rzeczypospolitej Polskiej z 2 kwietnia 1997 r. uchwalona 2 kwietnia 1997 r., przyjęta w drodze referendum 25 maja 1997 r., Dz. U. 1997, Nr 78, poz. 483, ze zm. (dalej jako: Konstytucja).

${ }^{8}$ Pozostałe elementy ustroju samorządu określone Konstytucją jako mniej doniosłe z punktu widzenia opracowania, pomijam.

${ }^{9}$ Por. np. Chmielnicki (2006): 33-34, gdzie autor wskazuje na negatywne konsekwencje przyjęcia innych interpretacji.

${ }^{10}$ Próby oceny zgodności polskich regulacji samorządowych z EKSL dokonali np. Lipowicz (1991): 75-83, oraz Kieres (1998): 3-80.

${ }^{11}$ Zob. Lipowicz (1991): 78. 
podstawy działalności samorządu określone mają być prawem pochodzącym od organów państwa. Konsekwencją tego jest obowiązek zapewnienia przez państwo zgodności działań samorządu z prawem oraz stworzenia mechanizmów zapewniających ochronę samorządu przed nieuzasadniona, nadmierną ingerencją w swobodę realizacji jego zadań.

W art. 4 ust. 1 EKSL wskazano, że podstawowe zadania samorządu powinny być określone konstytucją lub ustawami, a więc aktami pochodzacymi od władzy ustawodawczej. Zapewnia to samorządowi ochronę przed nieznajdująca umocowania ustawowego ingerencja państwa w swobodę realizacji zadań i gwarantuje samorządom stabilne podstawy prawne ich funkcjonowania. Nadto w art. 4 ust. 1 EKSL rozróżniono dwie grupy powierzonych samorzadowi zadań, z którymi związany jest odmienny zakres swobody ich realizacji.

Kompetencje mające służyć realizacji zadań podstawowych, określanych także jako własne ${ }^{12}$, wykonywane mają być w granicach określonych prawem na własną odpowiedzialność przez samorząd dysponujacy pełną swobodą działania (art. 4 ust. 2 EKSL). Podstawą jej ograniczania może być wyłącznie przepis prawa (art. 4 ust. 4 EKSL). Także działania nadzorcze wymagaja zatem prawem sprecyzowanych podstaw prawnych. W odniesieniu do delegowanych na samorząd zadań organów centralnych lub regionalnych, określanych jako zlecone ${ }^{13}$, wskazuje się, że samorząd powinien mieć zapewniona pełną swobodę w dostosowaniu sposobów ich wykonywania do warunków lokalnych (art. 4 ust. 5 EKSL). Odmiennie akcentowany zakres swobody działań samorządu dla obu grup zadań i kompetencji przekłada się na odmienność dopuszczalnych kryteriów sprawowania nadzoru nad ich wykonywaniem (zob. art. 8 ust. 2 EKSL).

Postanowienia dotyczace nadzoru wydzielono w Karcie w art. 8: „Kontrola administracyjna działalności społeczności lokalnych”. Sprawowany przez administrację państwową nadzór nad samorządem terytorialnym w wersji polskiej przetłumaczono jako „kontrola administracyjna”. Nie chodzi tu jednak o kontrolę rozumiana jako weryfikacja zgodności działań samorządu z przyjętymi jako wzorcowe, ale o dopuszczalną ingerencję państwa w działalność oraz rezultaty działalności organów samorządu na wypadek zaistnienia nieprawidłowości ${ }^{14}$. Stąd też dalej posługiwać się będę określeniem „nadzór”.

W art. 8 ust. 1 EKSL wskazano, że nadzór nad samorządem terytorialnym sprawowany ma być wyłącznie w formach oraz przypadkach przewidzianych w konstytucji lub w ustawie. Stanowi to kanon administracji zdecentralizowanej, formułowany w nauce prawa administracyjnego już od dziesięcioleci ${ }^{15}$. Wyrażono w ten sposób zasadę ograniczania ingerencji państwowej w działania samorządu do przypadków wyraźnie wskazanych przez ustrojodawcę bądź ustawodawcę, gwarantując samorządom samodzielność w realizacji powierzo-

${ }^{12}$ Zob. np. Niewiadomski (2011b): 137-144 i cytowana tam literatura.

${ }^{13}$ Zob. przypis wyżej.

${ }^{14}$ Na temat rozróżnienia pojęć „kontroli” i „nadzoru” Zob. np. Niewiadomski (2011a): 196207 oraz literatura tam cytowana, a także Ziemski (2016): 671-689.

${ }_{15}$ Zob. np. Starościak (1975): 61-62; Niewiadomski (1988): 99 n.; Dolnicki (1993): 24 n., Leoński (1998): 229-230, oraz Fundowicz (1999): 64-71. 
nych im zadań (art. 8 ust. 1 EKSL). W tytule art. 8 EKSL wskazano, że chodzi o nadzór sprawowany przez władzę administracyjna. Chodzi tu o ingerencję sprawowana przez administracje państwa. W Karcie nie wskazano na konieczność określania w konstytucji bądź ustawach organów nadzoru, jednakże bez określenia podmiotu kompetentnego nie można prawidłowo skonstruować jakichkolwiek norm udzielających kompetencji ${ }^{16}$. Przesądza to o potrzebie wskazania w konstytucji bądź ustawach także organów nadzoru.

W art. 8 ust. 2 EKSL określono kryteria sprawowania nadzoru, różnicując je w zależności od rodzaju realizowanych zadań, w nawiązaniu do art. 4 ust. 2 EKSL, akcentującego swobodę samorządu w realizacji jego zadań. Nadzór nie może zatem wykluczać czy choćby nadmiernie ograniczać tejże swobody. Wyłącznie w przypadkach niezbędnych dla ochrony innych wartości, w danej sytuacji ocenianych jako nadrzędne, dopuścić można zatem ingerencję nadzorcza.

Wszelki nadzór nad samorządem terytorialnym, w świetle art. 8 ust. 2 zd. 1 EKSL, co do zasady sprawowany ma być celem zapewnienia zgodności jego działań z prawem oraz z zasadami konstytucyjnymi ${ }^{17}$. W zd. 2 art. 8 ust. 2 EKSL wskazano, że nadzór nad realizacją zadań zleconych dopuszczalny jest także z punktu widzenia celowości. Stanowić to ma jednak wyjątek od zasady sprawowania nadzoru z punktu widzenia legalności ${ }^{18}$.

Wyrażona w art. 8 ust. 3 EKSL zasada proporcjonalności przesądza o dopuszczalnym zakresie ingerencji nadzorczej. Ma ona być proporcjonalna do wagi chronionego interesu. Nieuzasadnione wkraczanie oraz nadzorcze stosowanie środków nadmiernie ingerujących w swobodę działania samorządu stanowi jej naruszenie. Wywodzić stąd można zasady bardziej szczegółowe, instrumentalne do zasady proporcjonalności, jak choćby obowiązek zróżnicowania środków ingerencji, pozwalając na dostosowanie środka ingerencji do doniosłości chronionych interesów oraz wagi naruszenia prawa czy umocowania organów nadzoru do podejmowania działań prewencyjnych, edukacyjnych i innych.

\section{CHARAKTERYSTYKA TYTUŁOWYCH ŚRODKÓW NADZORU PRZYJĘTYCH W USTAWACH USTROJOWYCH DOTYCZĄCYCH GMIN ${ }^{19}$}

Pierwotnie w ustawie o samorzadzie terytorialnym przewidywano, że nadzór sprawowany jest z punktu widzenia legalności (art. 85 ust. 1 u.s.g.), a w sprawach zleconych - także celowości, rzetelności oraz gospodarno-

\footnotetext{
16 Zob. np. Ziembiński (1969): 23-41.

17 Przestrzeganie zasad konstytucyjnych wymagałaby odrębnego omówienia, co jednak wykracza poza ramy niniejszego opracowania.

18 Zob. np. Korczak (2012): 245 n.

19 Zob. przypis 1 oraz ustawa z 7 października 1992 r. o regionalnych izbach obrachunkowych, t.jedn.: Dz. U. 2019, poz. 2137 (dalej jako: u.r.i.o.).
} 
ści (art. 85 ust. 2 u.s.g.), co odpowiadało standardom przyjętym w Karcie. W art. 87 u.s.g. wskazano, że organy nadzorcze mogą wkraczać w działalność samorządu tylko w przypadkach określonych ustawowo.

Środkiem nadzoru, mającym za cel wyeliminowanie z obrotu wadliwych uchwał organów JST - co do istoty niezmienionym do dzisiaj - jest stwierdzenie nieważności wadliwej uchwały organu samorządu w całości bądź w części (art. 91 u.s.g.). Środek ten początkowo stosowany był w odniesieniu do uchwał organów gminy (rady i zarządu), a obecnie uchwał oraz zarządzeń monokratycznego organu wykonawczego ${ }^{20}$, wydawanych w zakresie realizacji wszystkich zadań ${ }^{21}$. Już w pierwotnej wersji art. 91 ust. 1 u.s.t. skutek nieważności rozstrzygnięć organów samorządu przesądzony został przez ustawodawcę wobec zaistnienia wady w postaci sprzeczności z prawem ${ }^{22}$, przez którą rozumieć należy istotne naruszenie prawa. W tym zakresie regulacja ta nie uległa zmianom do chwili obecnej. Obowiązkowe stwierdzenie nieważności aktu zapewnić ma pewność obrotu prawnego przez pozbawienie go przymiotu legalności, i to od chwili jego wydania (ex tunc), potwierdzając tym samym, że wada musi być poważna. W rezultacie przyjmujemy fikcję, że wadliwy akt nigdy nie pozostawał w obrocie prawnym jako mogacy wywoływać skutki prawne ${ }^{23}$.

Określony art. 91 ust. 1 u.s.g. stosunkowo krótki (30 dni) okres pozostawiony na rozstrzygnięcie nadzorcze w przedmiocie stwierdzenia nieważności przesądza o jego charakterze represyjnym, za jedyny cel majacym wyeliminowanie wadliwego aktu z obrotu prawnego, wykluczając możliwość podjęcia przez organy gminy działań naprawczych. Zakreślony na wydanie tego środka termin oraz brak po stronie nadzorowanych, aż do chwili otrzymania rozstrzygnięcia nadzorczego, wiedzy o istniejących naruszeniach prawa czyniłoby jego podejmowanie bezzasadnym. Zresztą wobec nieważności wadliwego aktu z mocy ustawy celowość podejmowania działań naprawczych jest watpliwa.

Środkiem nadzoru adresowanym do wadliwych uchwał organów gminy był środek uregulowany uchylonym art. 95 u.s.t. ${ }^{24}$, a więc możliwość wstrzymania wykonania uchwały przez wojewodę z jednoczesnym przekazaniem aktu do ponownego rozpoznania wraz ze wskazaniem stwierdzonych uchybień oraz terminu załatwienia sprawy (art. 95 ust. 1 u.s.t.). Wstrzymanie wykona-

${ }^{20} \mathrm{~W}$ pierwotnym tekście u.s.t. była mowa o uchwałach organów gminy, ponieważ zarówno organ stanowiący, jak i wykonawczy gminy (zarząd) były organami kolegialnymi, w wyniku nowelizacji zmieniony został art. 43 pkt 2 oraz art. 43 pkt 46 lit. a) ustawy z 20 czerwca 2002 r. o bezpośrednim wyborze wójta, burmistrza i prezydenta miasta (t.jedn.: Dz. U. 2010, Nr 176, poz. 1191). Zmiana sprowadzała się do zastapienia zarządu gminy organem monokratycznym, wójtem (burmistrzem, prezydentem miasta).

${ }^{21}$ Zob. np. Adamiak (2002): 15-24. Por. np. wyrok NSA z 20 czerwca 2007 r., II OSK 298/07, Lex nr 341373, oraz wyrok NSA z 5 lipca 2017 r., II OSK 1106/17, Lex nr 1672373.

22 Por. np. wyrok NSA z 12 października 1990 r., SA/Lu 663/90, ONSA 1990, nr 4, poz. 6, oraz uzasadnienie wyroku WSA w Kielcach z 4 stycznia 2017 r., II SA/Kl 1026/16, Lex nr 2786471.

${ }^{23}$ Zob. np. Dolnicki (1993): 116; (1997): 45-53, a także Chmielnicki (2006): 220.

24 Art. 95 u.s.t. uchylono art. 1 pkt 61 ustawy z 11 kwietnia 2001 r. o zmianie ustaw: o samorządzie gminnym, o samorządzie powiatowym, o samorządzie województwa, o administracji rządowej w województwie oraz o zmianie niektórych innych ustaw, Dz. U. 2001, Nr 45, poz. 497. 
nia stanowiło element obligatoryjny tego środka nadzoru ${ }^{25}$. Stosowanie tego środka ograniczono do nadzoru nad realizacją zadań zleconych, co do których uchylony art. 85 ust. 2 u.s.g. ${ }^{26}$ dopuszczał działania nadzorcze według kryterium celowości, rzetelności oraz gospodarności. Wobec uregulowania konsekwencji nieważności aktów art. 91 u.s.g. środek ten dotyczył pozostałych, lżejszych przypadków naruszeń prawa, w art. 91 ust. 4 u.s.g. określonych jako nieistotne.

Obowiązkiem organów gminy było usunięcie wskazanych uchybień, jednakże decyzję co do sposobu załatwienia sprawy (tj. sposobu usunięcia wad) pozostawiono nadzorowanym. W przypadku nieuwzględnienia wskazań wojewodę umocowano do uchylenia kwestionowanej uchwały oraz wydania zarządzenia zastępczego, co pozwalało zapewnić zgodność uchwał z określonymi kryteriami, w tym legalności, w sposób nieograniczający swobody działania samorządu, czyniąc zadość wyrażonej w art. 8 ust. 3 EKSL zasadzie proporcjonalności. Rozwiązanie to przewidywało dopuszczony Kartą nadzór celowościowy nad realizacja zadań zleconych, pozwalając na pełniejszą realizację tej zasady przez umożliwienie podejmowania działań autonaprawczych oraz pozostawienie organom samorządu decyzji, co do sposobu usunięcia wady. W odniesieniu do zadań zleconych przewidywano nadzór legalności nie tylko w przypadkach sprzeczności z prawem, umożliwiając podejmowanie działań autokontrolnych, zapewniających adekwatność środków do stwierdzonych naruszeń, a przez to skuteczniejszą realizację zasady praworządności. Rozwiązania przyjęte uchylonym art. 95 u.s.g. wskazuja, że dostrzegano potrzebę odróżniania sprzeczności z prawem skutkującej nieważnością uchwały od przypadków niezgodności z prawem wymagać mogących zmiany czy uchylenia wadliwej uchwały ze skutkiem na przyszłośćc ${ }^{27}$.

Kolejny środek przewidziano ustawą o regionalnych izbach obrachunkowych, w który wyposażono regionalne izby obrachunkowe (dalej: RIO). W art. 12 u.r.i.o. przewidziano szczególny tryb postępowania w przedmiocie stwierdzenia nieważności uchwał budżetowych. Działania określone w art. 91 ust. 1 u.s.g. uzupełniono o kompetencję RIO do wskazania nieprawidłowości uchwały budżetowej oraz sposobu i terminu ich usunięcia. Środek ten w zakresie trybu podobny jest do określonego art. 95 u.s.g. O ile jednak regulacje art. 95 u.s.g. dotyczyły nieistotnych przypadków naruszeń prawa, o tyle środek określony art. 12 u.r.i.o. dotyczy sprzeczności uchwał budżetowych z prawem. Stwierdzenie nieważności kwestionowanej uchwały w całości bądź w części następuje dopiero wobec nieusunięcia nieprawidłowości przez radę gminy w drodze działań autokontrolnych w terminie i w sposób wyznaczonych przez RIO.

${ }^{25}$ Dolnicki (1993): 120-121.

${ }^{26}$ Art. 85 ust. 2 u.s.g. uchylono art. 1 pkt 52 ustawy z 11 kwietnia 2001 r. o zmianie ustaw: o samorządzie gminnym, o samorządzie powiatowym, o samorządzie województwa, o administracji rządowej w województwie oraz o zmianie niektórych innych ustaw, Dz. U. 2001, Nr 45, poz. 497.

27 Pomijam dalszą możliwość podejmowania rozstrzygnięcia zastępczego przez organ nadzoru jako środka nieobjętego przedmiotem opracowania. 
Rozwiąanie to, z punktu widzenia ochrony interesów samorządu, wydaje się korzystne. Jednak relatywnie krótki czas, jaki zakreślić może organ nadzoru, a nadto obowiązek określenia sposobu usunięcia wady istotnie ograniczaja, a niekiedy wręcz wykluczają swobodę działania samorządu. Określając czas na autokorektę, RIO uwzględniać musi, że niezrealizowanie jej wskazań w zakreślonym terminie, przed upływem terminu z art. 91 ust. 1 u.s.g. podjąć musi rozstrzygnięcie $\mathrm{w}$ przedmiocie stwierdzenia nieważności oraz zastępczo ustalić budżet w części dotkniętej wadą (art. 12 ust. 3 u.r.i.o.). Określony art. 91 ust. 1 u.s.g. termin ulega co prawda zawieszeniu, jednak nie dłużej niż na 30 dni (art. 12 ust. 4 u.r.i.o.). W tym czasie nastapić ma doręczenie wezwania do usunięcia nieprawidłowości organowi nadzorowanemu, przygotowanie projektu uchwały zmieniającej, zwołanie sesji rady, podjęcie uchwały oraz doręczenie jej organowi nadzoru.

W świetle określonej Kartą zasady proporcjonalności zasadność takiego rozwiązania budzi uzasadnione wątpliwości. Nadto wyłączną podstawą wskazania nieprawidłowości przez RIO jest sprzeczność uchwały z prawem jako przesłanka jej nieważności, co powinno wykluczać pozostawienie radzie gminy możliwości usunięcia stwierdzonej już przez RIO wady. Sposób usunięcia wady zdeterminowany jest rodzajem naruszenia prawa (sprzeczność z prawem), a wskazanie sposobu jej usunięcia przez RIO wyklucza, a przynajmniej istotnie ogranicza, swobodę działania rady gminy.

Dostrzegając potrzebę istnienia środka pozwalającego na podjęcie działań autokontrolnych, nie uwzględniono charakteru przesłanki, od której uzależniono jego stosowanie. Wobec stwierdzenia przez RIO sprzeczności uchwały z prawem możliwość działań autokontrolnych zapewniona jest tylko formalnie, a przyjęte rozwiązanie nie zapewnia realizacji przyjętych Karta zasad proporcjonalności oraz swobody działania samorządu. Środek ten różni się istotnie od przewidzianego art. 95 u.s.g., gdzie możliwość podejmowania działań autokontrolnych dotyczyła naruszeń prawa innych niż sprzeczność, a organ nadzorczy nie determinował sposobu usunięcia wady.

W analizach dotyczących omawianych środków nadzoru nie można pominać komplementarnego w stosunku do nich środka zapobiegawczego. Wszczynając postępowanie w przedmiocie stwierdzenia nieważności, organ nadzoru fakultatywnie wstrzymuje wykonanie danego rozstrzygnięcia ${ }^{28}$ (art. 91 ust. 2 u.s.g.). Skuteczne jest ono do chwili zakończenia postępowania nadzorczego albo bezskutecznego upływu 30-dniowego terminu zakreślonego organom nadzoru do przesądzenia w przedmiocie nieważności (art. 91 ust. 1 u.s.g.).

Zapobiega to negatywnym skutkom danego aktu do czasu wyeliminowania go z obrotu prawnego. Zastrzeżenia budzić może fakultatywność stosowania tego środka. Wszczęcie przez organ postępowania w przedmiocie stwierdzenia nieważności wskazuje, że w jego ocenie uzasadnione jest podejrzenie sprzecz-

${ }_{28}$ Tak np. Dolnicki (1993): 113; Chmielnicki (2013): 923. Por. także postanowienie NSA z 18 października 2017 r., II OSK 2380/17, w którym podkreślono wagę wstrzymania wykonania jako środka nadzoru. Odmienne stanowisko zają WSA w Szczecinie w postanowieniu z 26 października 2015 r., II SA/Sz 1181/15, Lex nr 1819053, w którym zakwestionował kwalifikowanie wstrzymania wykonania jako środka nadzoru. 
ności aktu z prawem, co skutkować powinno albo wstrzymaniem wykonania nadzorowanego aktu z mocy ustawy, albo obligatoryjnym wstrzymaniem przez organ nadzoru. Rozwiązanie z takim właśnie skutkiem, choć nieco inaczej skonstruowane, przyjęto uchylonym art. 95 u.s.g., gdzie wojewoda, przekazując sprawę do ponownego rozpatrzenia, obowiązkowo wstrzymywał wykonanie aktu.

\section{CHARAKTERYSTYKA PRÓBY NOWEGO UREGULOWANIA TYTUŁOWYCH ŚRODKÓW}

Ujawnione wątpliwości co do przyjętych regulacji, a zwłaszcza ograniczenia działań nadzorczych wyłącznie do przypadków skutkujących nieważnościa, skłaniały do podjęcia próby wprowadzenia zmian w tym zakresie. Przykładowo, regulację taką zawarto w projekcie ustawy o współdziałaniu w samorządzie terytorialnym na rzecz rozwoju lokalnego i regionalnego oraz o zmianie niektórych ustaw, przedłożonym Sejmowi VII kadencji ${ }^{29}$ (dalej: Projekt), który jednak nie został uchwalony ${ }^{30}$.

W art. 39 pkt 38 Projektu zaproponowano diametralnie odmienną treść art. 91 u.s.g. W myśl Projektu działania nadzorcze miały być podejmowane w każdym przypadku naruszenia prawa, a nie wyłącznie sprzeczności z prawem. Organ nadzoru kierowałby do właściwego organu gminy informacje o stwierdzonych naruszeniach prawa (art. 91 ust. 1 według Projektu). Stanowiłaby ona środek nadzorczy przesądzający wyłącznie o wystapieniu naruszeń prawa. Organom nadzoru przyznano kompetencje do wstrzymania wykonania wadliwego aktu, jednakże w przypadku stwierdzenia istotnych naruszeń prawa organ obowiązkowo wstrzymywałby jego wykonanie (art. 91 ust. 3 według Projektu), wyznaczając jednocześnie termin do usunięcia stwierdzonych naruszeń prawa. Bezskuteczny upływ tego terminu obligował organ nadzoru (podobnie jak w art. 12 ust. 2 u.r.i.o.) do stwierdzenia nieważności uchwały lub zarządzenia w całości lub w części.

Regulacje zaproponowane Projektem obarczone sa istotnymi niedostatkami. Podstawą wszczęcia postępowań nadzorczych mogłoby być każde naruszenie prawa, jednak środkiem nadzoru, przewidzianym na wypadek nieusunięcia stwierdzonych wad drogą autokontroli, miałoby być stwierdzenie nieważności uchwały lub zarządzenia w całości albo w części (art. 91 ust. 4 według Projektu). Przyjętą Projektem przesłanką stwierdzenia nieważności miało być „istotne naruszenie prawa”, a nie jak obecnie „sprzeczność z prawem”.

Zaproponowana Projektem zmiana zmierzała do zaakcentowania, że nie tylko przypadki rażącej wadliwości w postaci sprzeczności z prawem, ale tak-

${ }^{29}$ Przedstawiony w sierpniu 2013 r. przez Prezydenta Rzeczypospolitej Polskiej projekt ustawy o współdziałaniu w samorządzie terytorialnym na rzecz rozwoju lokalnego i regionalnego oraz o zmianie niektórych ustaw. Druk nr 1699.

${ }^{30}$ Proces legislacyjny zakończono na I czytaniu w Sejmie. Do dalszej procedury nie doszło w wyniku niekontynuowania procesu legislacyjnego przez Sejm kolejnej kadencji. 
że przypadki pozostałych, istotnych naruszeń prawa miałyby być podstawa stwierdzenia nieważności. Skutkowałoby to obligatoryjnym eliminowaniem z obrotu prawnego, i to z mocą wsteczna, szerszego zakresu aktów niż określony obowiązującym art. 91 ust. 1 u.s.g.

Zaproponowane w Projekcie rozwiązanie stanowiło próbę zaradzenia trudnościom ze sprecyzowaniem pojęcia „sprzeczność z prawem” oraz potrzebie rozszerzenia nadzoru na przypadki inne niż rażące uchybienia prawu, jednak zmiana przesłanki ingerencji, przy pozostawieniu drastycznej konsekwencji w postaci nieważności aktu, nie zapewniała osiąnięcia założonego celu. Stworzenie możliwości podejmowania działań autonaprawczych umożliwiało spełnienie wymogu proporcjonalności, jednak ingerencja nadzorcza na wypadek niepodjęcia działań naprawczych w postaci stwierdzenia nieważności uniemożliwiała jej realizację. Przypomnijmy, że uchylony art. 95 u.s.g dopuszczał możliwość ingerencji w przypadku lżejszych naruszeń prawa, ale wyłącznie w odniesieniu do zadań zleconych. Dostrzegana jest zatem potrzeba odróżniania przypadków naruszeń skutkujących nieważnością od innych, które moga wymagać ingerencji nadzorczej już wcześniej. Przyjęte w Projekcie regulacje potwierdziły to, jednak nie stanowiły one dobrej próby ich zaradzenia.

\section{CHARAKTERYSTYKA SPRZECZNOŚCI Z PRAWEM JAKO PRZESŁANKI STOSOWANIA TYTUŁOWYCH ŚRODKÓW INGERENCJI}

Powyższe analizy omawianych środków nadzorczych wskazuja, że jednym ze źródeł trudności ich stosowania sa problemy ze sprecyzowaniem przesłanki ich stosowania ${ }^{31}$. Potwierdza to wynik kontroli działań nadzorczych wojewodów nad stanowieniem prawa przez organy JST, opublikowany w 2020 r. przez Najwyższą Izbę Kontroli ${ }^{32}$. W raporcie wskazano na rozbieżności orzecznictwa wojewodów dotyczące podstaw stwierdzenia nieważności oraz ich konsekwencje. Wskazano m.in., że w ponad 40\% aktów niezakwestionowanych stwierdzono regulacje, które w innych przypadkach stanowiły podstawę stwierdzenia nieważności ${ }^{33}$. Wskazano także, że wojewodowie odstępowali od stosowania środka nadzoru wobec zobowiązania się organów gmin do uchylenia bądź zmiany wadliwych uchwał. Potwierdza to trudności w zdefiniowaniu pojęcia

${ }^{31}$ Zwracał na to już uwagę dużo wcześniej Dolnicki (1993): 115-116. Zob. także wyrok WSA w Warszawie z 11 marca 2007 r., IV SA/Wa 2296/06, Lex nr 320813; oraz wyrok NSA z 15 września 2017 r., I OSK 1136/17, Lex nr 1690421.

32 Informacja o wynikach kontroli Delegatury NIK w Warszawie w odniesieniu do nadzoru wojewodów nad stanowieniem prawa przez organy jednostek samorządu terytorialnego, nr ewid. 186/2019/P/19/103/LWA, dostępna na: <www.nik.gov.pl>. Kontrolą objęto okres od 2017 r. do I kwartału 2019 r.

${ }^{33} \mathrm{~W}$ raporcie trafnie wskazano, że „Skutkiem tego [...] uchwały naruszające te same przepisy prawa zostały rozstrzygnięciami nadzorczymi wyeliminowane z obrotu prawnego, podczas gdy w innych jednostkach samorządu terytorialnego, wobec nie podjęcia tych rozstrzygnięć [nadzorczych - K.Z.], akty takie obowiązywały nadal, jako zgodne z prawem”. 
„sprzeczność z prawem” oraz ujawnia brak rozumienia istoty nieważności aktu. Rezygnacja ze stwierdzenia nieważności skutkuje nie tylko uchybieniem obowiązkowi dokonania tego, ale - co gorsza - pozostawieniem organom gminy możliwości zmiany bądź uchylenia aktu z mocy ustawy nieważnego. Pomija się w ten sposób, że skutkiem uchylenia bądź zmiany jest wyeliminowanie aktu ex nunc, a nie ex tunc jak w przypadku aktów nieważnych ${ }^{34}$.

Kwalifikowanie niektórych naruszeń prawa raz jako podstawy stwierdzenia nieważności, a raz jako nieistotnego jedynie naruszenia prawa jest rezultatem przesądzenia w art. 91 ust. 4 u.s.t., że wobec braku podstaw do stwierdzenia nieważności organ wskazuje jedynie, że akt wydano z nieistotnym naruszeniem prawa. Obok niedającej się pogodzić z porządkiem prawnym sprzeczności z prawem odróżnia się naruszenia jedynie nieistotne, niestanowiace podstaw do podejmowania działań nadzorczych ${ }^{35}$. Wskazanie takie kwalifikowane jest jako sygnalizacja, na którą nie przysługuje gminie skarga ${ }^{36}$. Zastapienie w Projekcie „sprzeczności z prawem”, jako przesłanki nieważności, „wadliwością istotną" nie eliminuje problemu z kwalifikowaniem aktów albo jako wadliwych ze skutkiem nieważności, albo jako wadliwych jedynie nieistotnie.

Skutek nieważności rozstrzygnięcia jest na gruncie prawa administracyjnego znany w odniesieniu do decyzji administracyjnych wydawanych w trybie k.p.a. ${ }^{37} \mathrm{~W}$ u.s.g. w odniesieniu do stwierdzenia nieważności rozstrzygnięć organów gminy, w art. 91 ust. 5, wskazano, że odpowiednie zastosowanie znajda tutaj przepisy k.p.a., co zdaje się uzasadniać próbę sprecyzowania przesłanki stwierdzenia nieważności uchwał lub zarządzeń organów gminy z odwołaniem się do ustaleń poczynionych na gruncie k.p.a.

Przyjęta na gruncie u.s.g. klasyfikacja wadliwości na skutkująca nieważnościa albo nieistotna kontrastuje jednak z ukształtowaną na gruncie k.p.a. gradacją wad aktów indywidualnych ${ }^{38}$. Obok podlegającej konwalidacji wadliwości nieistotnej (przez uzupełnienie bądź sprostowanie) występuje wadliwość istotna, wymagająca zmiany bądź uchylenia aktu ze skutkiem na przyszłość, oraz wadliwość, skutkująca nieważnością wymagająca stwierdzenia tego przez właściwy organ ze skutkiem ex tunc (art. $156 \S 1$ k.p.a.). Chociaż konsekwencje nadzorczego stwierdzenia nieważności uchwał czy zarządzeń co do istoty podobne są do konsekwencji nieważności decyzji ${ }^{39}$, to jednak rozróżnianie na

${ }^{34}$ Zob. uzasadnienie wyroku NSA z 27 września 2007 r., II OSK 1046/07, Lex nr 384291, oraz wyrok NSA z 17 lutego 2016 r., II FSK 3595/13, Lex nr 1454742. Dolnicki (2005): 478; a także Kmieciak (1995): 38.

35 Por. np. wyrok WSA w Olsztynie z 30 listopada 2017 r., II SA/Ol 819/17, Lex nr 2414261.

36 Por. postanowienie NSA we Wrocławiu z 16 kwietnia 2002 r., II SA/Wr 2151/00, Lex nr 54845.

${ }^{37}$ Konstrukcja ta doczekała się licznych opracowań oraz bogatego orzecznictwa. Zob. np. Adamiak, Borkowski (2019): 904-946 oraz literatura tam cytowana, a także Jaśkowska (2020): 858-879 oraz literatura tam cytowana.

${ }^{38}$ Bliżej o gradacji wadliwości decyzji administracyjnej i jej konsekwencjach zob. np. Adamiak (2012): 45-54 oraz literatura tam cytowana.

${ }^{39}$ Zob. w szczególności stanowisko Adamiak przywołane w przyp. 21 oraz stanowisko przywołane w przyp. 36, a także wyrok NSA z 5 lipca 2017 r. przywołany w przyp. 21. 
gruncie k.p.a. trzech rodzajów wadliwości, o różnych przesłankach i konsekwencjach, dyskusyjnym czyni dopuszczalność bezpośredniego odwoływania się do przesłanek nieważności decyzji, celem sprecyzowania pojęcia „sprzeczność z prawem” jako przesłanki stwierdzenia nieważności rozstrzygnięć organów gminy.

Brak na gruncie u.s.g. wadliwości istotnej, nieskutkującej nieważnościa oraz brak możliwości podejmowania w stosunku do nich działań nadzorczych, skutkuje próbami kwalifikowania ich albo jako przypadków nieistotnego naruszenia prawa, albo jako przypadków skutkujących nieważnością. Skalę, a także wagę negatywnych zjawisk związanych z tymi niedostatkami ujawniają z całą ostrością przywołane wyniki badań NIK ${ }^{40}$. Wątpliwości oraz problemów stąd wynikłych nie można rozwiązać drogą interpretacji. Najwyraźniej potrzebna jest tutaj ingerencja prawodawcza.

\section{PRÓBA CHARAKTERYSTYKI ZASAD STOSOWANIA TYTULOWYCH ŚRODKÓW W NIEMCZECH}

W art. 95 u.s.g., art. 12 u.r.i.o. oraz art. 91 u.s.g. w wersji projektowanej nowelizacją (art. 39 pkt 38 Projektu) w zakresie tytułowych środków nawiązuje się do rozwiązań przyjętych w niemieckich samorządowych ustawach ustrojowych. Odpowiednikiem tytułowych działań nadzorczych jest środek określany jako „Beanstandung”, co przetłumaczyć można jako „zakwestionowanie” ${ }^{41}$.

Obejmuje ono w istocie dwa odrębne, ściśle ze sobą funkcjonalnie powiązane środki nadzoru ${ }^{42}$. Pierwszym jest wskazanie przez organ nadzoru naruszenia prawa kwestionowanym rozstrzygnięciem. Drugim jest skierowane do organów gminy żądanie wyeliminowania stwierdzonych zakwestionowaniem wadliwości w zakreślonym przez organ nadzoru terminie (Aufhebungsverlangen).

Istotą zakwestionowania jest autorytatywne wypowiedzenie się przez organ nadzoru co do istnienia wad rozstrzygnięcia. Stosowane może być wyłącznie w sytuacjach, gdy stwierdzona wadliwość jest na tyle istotna, że stanowić może podstawę skierowania żądania usunięcia stanu wadliwości ${ }^{43}$. Stanowi to wyraz respektowania przez prawodawców niemieckich zasady proporcjonalności. Zastosowanie tego środka pozostawiono szeroko rozumianemu uznaniu organu nadzoru (Ermessen) ${ }^{44}$, który w przypadku naruszeń prawa, w jego

40 Zob. przyp. 31.

41 Środek ten tłumaczony jest także jako „zaskarżenie”, tak np. Meier (2018): 661.

42 Por. Lange (2013): 1146. Autor wskazuje tam także na środek ujmowany pod pojęciem „Beanstandung”, który jednak jako dotyczący eliminacji konsekwencji prawnych aktów uprzednio zakwestionowanych w opracowaniu pomijam.

${ }^{43}$ Lange (2013): 1148-1149, nb. 81.

${ }_{44}$ Bliżej na ten temat zob. np. Lange (2013): 1135, nb. 42. Uznania w tym ujęciu nie można utożsamiać z instytucją uznania czy też swobodnego uznania znaną z gruntu polskiej nauki prawa administracyjnego, a dotycząca możliwości wyboru przez organ administracji konsekwencji prawnych dla ustalonego stanu faktycznego. Bliżej na temat „uznania” zob. zwłaszcza Jaśkowska (2015): 229-261 oraz literatura tam cytowana. 
ocenie wymagających podjęcia działań nadzorczych, kwestionuje wadliwy akt. Podstawą zakwestionowania może być zarówno wada skutkująca nieważnością aktu, jak i wymagająca jego uchylenia bądź zmiany. Środek ten, podobnie jak wskazanie przewidziane art. 95 u.s.t. czy art. 12 u.r.i.o., nie eliminuje wadliwych aktów, lecz wskazuje nadzorowanym na istnienie wad wymagających ich usunięcia.

W żądaniu usunięcia naruszenia prawa określa się termin jego usunięcia z uwzględnieniem charakteru organu i przedmiotu rozstrzygnięcia, wagi stwierdzonej wady itd. celem rzeczywistego umożliwienia organom gminy podjęcia działań autokontrolnych. Nie określa się w nim jednak sposobu usunięcia wady. Środek ten nakierowany jest na zapewnienie możliwości podjęcia przez organ gminy działań autokontrolnych z poszanowaniem zasady swobody realizacji zadań oraz zasady proporcjonalności ${ }^{45}$.

Dopiero w przypadku nieusunięcia przez organy gminy w drodze autokontroli wad w zakreślonym terminie, organ nadzoru, w zależności od rodzaju stwierdzonej wady, eliminuje wadliwy akt z obrotu prawnego, odpowiednio stwierdzając jego nieważność albo uchylając go w całości albo części. W literaturze niemieckiej podkreśla się wręcz, że środek ten stosuje się także, a nie wyłącznie, w przypadku nieważności aktów ${ }^{46}$. Celem nadzoru nie jest zatem, tak jak w przypadku rozwiązań polskich, stwierdzenie nieważności, ale wyeliminowanie wadliwego aktu w sposób i z konsekwencjami adekwatnymi do stwierdzonej wady.

W przyjętych przez krajowych prawodawców niemieckich rozwiązaniach nie wyposażono organów nadzoru w kompetencje do wstrzymywania wykonania wadliwego aktu. Następuje to z mocy prawa, wskutek zakwestionowania rozstrzygnięcia. Jest ono skuteczne do momentu usunięcia wady w drodze autokontroli, w przypadku niepodjęcia działań autokontrolnych - do momentu wyeliminowania wadliwego aktu przez organ nadzoru ${ }^{47}$.

\section{PODSUMOWANIE}

Przegląd analizowanych środków nadzoru wykazał, że polski prawodawca przyją restrykcyjny model nadzoru, zapewniający szybką eliminację z obrotu prawnego wyłącznie rozstrzygnięć rażąco uchybiających prawu. Jedynie $\mathrm{w}$ odniesieniu do uchwał budżetowych przyjęto rozwiązanie stwarzające or-

${ }^{45}$ Por. Lange (2013): 1149, nb. 82.

${ }^{46}$ Bliżej zob. np. Lange (2013): 1151, nb. 88. W niektórych krajach przyjęto odmienne środki zapewniające negatywnym następstwom wadliwych aktów, o których bliżej Lange (2013): 1152, nb. 91. W niektórych krajach przyjęto rozwiązania umocowujące organy nadzoru do podjęcia działań zastępczych, eliminujących wadliwy akt, a nawet możliwość wydania w miejsce aktu wadliwego aktu wolnego od wad, z którym to rozwiązaniem spotykaliśmy się na gruncie art. 95 u.s.g. i obecnie art. 12 u.r.i.o.

${ }_{47}$ Por. Lange (2013): 1152, nb. 90. Pomijam problem wstrzymania wykonalności opublikowanych aktów, stanowiących odpowiednik aktów prawa miejscowego. 
ganom nadzorowanym możliwość podjęcia działań autokontrolnych, eliminujących wady skutkujące nieważnością uchwały. Z uwagi na charakter wady (sprzeczność z prawem) rozwiązanie to formalnie tylko pozostawia radzie gminy swobodę w zakresie zmiany wadliwej uchwały budżetowej. Krótki czas na usunięcie wady, a także zdeterminowanie sposobu jej usunięcia charakterem stwierdzonego naruszenia oraz obligatoryjnym wskazaniem przez RIO sposobu usunięcia wady pozwalają stwierdzić, że swoboda działania gminy jest tutaj praktycznie wykluczona, a możliwość podejmowania działań zgodnych z zasadą proporcjonalności zredukowana.

Prawodawca w art. 171 Konstytucji oraz art. 85 u.s.g. przewidział, że nadzór nad gminą sprawowany jest wyłącznie z punktu widzenia legalności. Choć w momencie przyjęcia u.s.g. (1990 r.) w art. 95 skorzystano z przewidzianej Kartą możliwości dopuszczenia nadzoru celowościowego nad realizacją zadań zleconych, jednakże uchylając go, z możliwości tej zrezygnowano. Na mocy art. 95 u.s.g. organy nadzoru dysponowały możliwością wezwania do usunięcia stwierdzonych naruszeń prawa nieskutkujących nieważnością, umożliwiając organom gminy podjęcie działań autokontrolnych. Dopiero ich niepodjęcie pozwalało na uchylenie wadliwej uchwały.

Wobec uchylenia art. 95 u.s.g. jedynym środkiem nadzoru stosowanym do uchwał oraz zarządzeń organów gminy pozostaje stwierdzenie ich nieważności (art. 91 u.s.t.). Dotyczy to także uchwał budżetowych, gdzie stwierdzenie nieważności poprzedzone musi być wezwaniem do usunięcia wady w określony sposób.

Ingerencję nadzorczą w rozstrzygnięcia organów gminy ograniczono zatem do minimum. Organy nadzoru wkraczać mogą wyłącznie w przypadkach skutkujących nieważnościa, wątpliwą czyniąc zasadność podejmowania działań autokontrolnych. Celem takiej regulacji jest zapewnienie daleko idącej ochrony samorządności gmin przed próbami nadmiernej ingerencji w swobodę realizacji zadań, rozwiązanie to jednak obarczone jest istotnymi niedostatkami.

Zapewniając szybką eliminację rozstrzygnięć rażąco wadliwych, zapobiega się skutkom ich pozostawania w obrocie prawnym, ale celem nadzoru ma być zapewnienie zgodności działań samorządu z prawem nie tylko na wypadek rażących uchybień. Ograniczenie możliwości działań nadzorczych w innych przypadkach naruszeń wyłącznie do wskazania na ich nieistotny charakter (art. 94 ust. 4 u.s.g.) nie wystarcza, co wykazał już przywołany raport NIK. Nie zapewnia to ochrony praw jednostki, której interesy mogą w ten sposób doznać uszczerbku, a także ochrony samej gminy przed konsekwencjami jej niezgodnych z prawem działań. W tym zakresie postanowienia Karty nie sa zatem $\mathrm{w}$ pełni realizowane.

Omawiane środki nadzoru przyjęte w Niemczech ukierunkowane sa na wszelkie przypadki naruszeń prawa wymagające ingerencji nadzorczej. Podkreślenia wymaga, że stosowanie tych środków nie jest tam głównym celem działań nadzorczych, lecz ostatecznościa. Odwołać można się do nich wobec nieskuteczności wcześniej podjętych działań. Zasada proporcjonalności oraz zasada samodzielności samorządu realizowane są przez umożliwienie samorządom podejmowania działań autokontrolnych, pozostawiając im przesądza- 
nie o sposobie usunięcia wad. Organy nadzoru zobowiązano wręcz do umożliwienia podjęcia takich działań z uwzględnieniem charakteru organu, od którego rozstrzygnięcie pochodzi, przedmiotu rozstrzygnięcia, rodzaju wady, trybu niezbędnego do wprowadzenia zmian itd. W przypadku niepodjęcia tych działań organy nadzoru, zgodnie z zasadą proporcjonalności, podejmują środki nadzorcze adekwatnie do stwierdzonego sposobu naruszenia prawa (stwierdzając nieważność bądź uchylając akt w całości albo części).

Przyjęty w Polsce system nadzoru nad działaniami gminy, pomimo zapewnienia w Konstytucji najwyższych standardów jego sprawowania, w świetle przyjętych rozwiązań ustawowych nie w pełni zapewnia realizację celów sprawowania nadzoru oraz zasad przewidzianych Karta. Choć ingerencję ograniczono do niezbędnego minimum, to nie zapewniono ani realizacji zasady proporcjonalności, ani ochrony praw jednostki, ani też samych samorządów przed skutkami ich niezgodnych z prawem działań.

Krystian Ziemski

Uniwersytet im. Adama Mickiewicza w Poznaniu

ziemskik@amu.edu.pl

https://orcid.org/0000-0001-6944-2251

Adamiak, B. (2002). Nieważność aktu prawa miejscowego a wadliwość decyzji administracyjnej. Państwo i Prawo 57(9): 15-24.

Adamiak, B. (2012). Gradacja naruszenia procesowego prawa administracyjnego. Państwo i Prawo $67(3)$ : $45-54$.

Adamiak, B., Borkowski, J. (2019). Komentarz do art. 156 k.p.a., [w:] B. Adamiak, J. Borkowski (red.), Kodeks postępowania administracyjnego. Komentarz. Wydanie 16. Warszawa: 904946.

Chmielnicki, P. (2006). Akty nadzoru nad działalnością samorządu terytorialnego w Polsce. Warszawa.

Chmielnicki, P. (2013). Komentarz do art. 91 u.s.g., [w:] P. Chmielnicki (red.), Ustawa o samorządzie gminnym. Komentarz. Warszawa: 923.

Dolnicki, B. (1993). Nadzór nad samorządem terytorialnym. Katowice.

Dolnicki, B. (1997). Klasyfikacja środków nadzorczych nad samorządem terytorialnym w ustawodawstwie polskim. Samorząd Terytorialny 7(6): 45-53.

Dolnicki, B. (2005). Ustawa o samorządzie powiatowym. Komentarz. Kraków.

Fundowicz, S. (1999). Jednostka samorządu terytorialnego (gmina, powiat, województwo) - konstrukcja prawna, [w:] S. Fundowicz (red.), Współczesne problemy prawa publicznego. Lublin: 64-71.

Jaśkowska, M. (2015). Pojęcie uznania administracyjnego, [w:] Z. Duniewska et al. (red.), System prawa administracyjnego. Tom 1: Instytucje prawa administracyjnego. Warszawa: 229-261.

Jaśkowska, M. (2020). Komentarz do art. 156 k.p.a., [w:] M. Jaśkowska, M. Wilbrandt-Gotowicz, A. Wróbel (red.), Kodeks postępowania administracyjnego. Komentarz. Wydanie 8. Warszawa: 858-879.

Kieres, L. (1998). Analiza zgodności polskiego prawa samorządu terytorialnego z Europejską Karta Samorząu Terytorialnego. Samorząd Terytorialny 8(9): 3-80.

Kmieciak, Z. (1995). Rozstrzygnięcie nadzorcze regionalnej izby obrachunkowej. Państwo i Prawo 50(2): 32-41.

Korczak, J. (2012). Konstytucyjne podstawy struktury i funkcji samorządu terytorialnego, [w:] R. Hauser, Z. Niewiadomski, A. Wróbel (red.), System prawa administracyjnego. Tom 2: Konstytucyjne podstawy funkcjonowania administracji publicznej. Warszawa: $245 \mathrm{n}$.

Lange, K. (2013). Kommunalrecht. Tübingen. 
Leoński, Z. (1998). Nadzór nad samorządem terytorialnym, [w:] A. Piekara, Z. Niewiadomski (red.), Samorząd terytorialny. Zagadnienia prawne i administracyjne. Warszawa: 229-230.

Lipowicz, I. (1991). Europejski standard samorządu terytorialnego a ustawodawstwo polskie. Samorząd Terytorialny 1(9): 75-83.

Meier, D. (2018). Nadzór i ochrona prawna, [w:] J. Jagoda (red.), Organizacja i funkcjonowanie samorządu terytorialnego w Polsce i w Niemczech. Analiza prawnoporównawcza. Warszawa: 661.

Niewiadomski, Z. (1988). Samorząd terytorialny w warunkach współczesnego państwa kapitalistycznego. Warszawa.

Niewiadomski, Z. (2011a). Nadzór nad samorządem terytorialnym, [w:] R. Hauser, Z. Niewiadomski, A. Wróbel (red.), System prawa administracyjnego. Tom 6: Podmioty administrujące. Warszawa: 196-207.

Niewiadomski, Z. (2011b). Tradycyjna konstrukcja zadań własnych i zleconych, [w:] R. Hauser, Z. Niewiadomski, A. Wróbel (red.), System prawa administracyjnego. Tom 6: Podmioty administrujace. Warszawa: 137-144.

Starościak, J. (1975). Prawo administracyjne. Wydanie 3. Warszawa.

Ziembiński, Z. (1969). Kompetencja i norma kompetencyjna. Ruch Prawniczy, Ekonomiczny i Socjologiczny 31(4): 23-41.

Ziemski, K. (2016). Czynności kontrolne a akty nadzoru - wyróżnianie i jego konsekwencje, [w:] B. Jaworska-Dębska et al. (red.), O prawie administracyjnym i administracji. Refleksje. Łódź: 671-689.

\section{SUPERVISION MEASURES FOR ELIMINATING THE DEFECTIVE DECISIONS OF MUNICIPAL AUTHORITIES - AN EVALUATION OF THE ADOPTED SOLUTIONS IN THE LIGHT OF THE EUROPEAN CHARTER OF LOCAL GOVERNMENT}

\section{Sum mary}

The democratic rule of law is a feature of local self-government corresponding to the presumptions defined in the European Charter of Local Self-Government (hereinafter: the Charter) Entrusting local self-governments with the performance of public tasks requires that they be subject to supervision to ensure the compliance of its activities with the law. According to the principle of proportionality, any interference with the activities of a self-government requires that the principle of freedom of execution be respected, which calls for the supervision to be restricted to the necessary extent. This paper analyses the compliance of Polish regulations on self-government with the Charter. Generally, the regulations stipulated in the Constitution of the Republic of Poland correspond to the requirements contained in the Charter. However, specific statutory solutions are not in full compliance with the rules specified in Article 8 of the Charter. The elimination of faulty decision from circulation is a measure aimed at ensuring the legality of the actions of a self-government. In the Polish regulations, the application of such measures is limited to infringements resulting in the invalidity of faulty acts. With the exception of budgetary resolutions, the possibility of commune or municipality bodies being able to take self-control measures in the event of infringements that required correction was eliminated, although this exists, for example, in German law. The possibility of applying supervisory measures adequate to the confirmed infringements was not provided. Similarly, the execution of all the aims of supervision was not ensured, in particular the full protection of an individual, or the commune or municipality itself, against the consequences of essential infringements of law by its respective bodies that do not result in invalidity.

Keywords: local self-government; control; supervision; elimination of faulty decisions 
